\title{
ANTIMICROBIAL ACTIVITY OF LEAF EXTRACTS OF SOME INVASIVE ALIEN PLANT SPECIES OF ASTER FAMILY AGAINST CLINICAL BACTERIA
}

\author{
Anita Sahu and Anjana Devkota* \\ Central Department of Botany, Tribhuvan University, Kathmandu, Nepal \\ *Email: devkotaa@gmail.com
}

\begin{abstract}
Aqueous and methanolic extracts of three plants at four different concentration viz. at 50, 100, 150 and $200 \mathrm{mg} / \mathrm{ml}$ were tested on clinical bacteria using the disc diffusion method. In vitro antibacterial activity was screened by using Nutrient Agar (NA). The qualitative phytochemical analysis depicted the presence of terpenoids, saponins, alkaloids, flavonoids, carotenes and glycosides in the plants. Results showed broad spectrum antimicrobial activity against the Gram-negative and Gram-positive bacteria. The methanol extract inhibited the growth of more bacteria compared to the aqueous extract. Results from in vitro study revealed that the antimicrobial activity might have been influenced by the solubility of active compound(s) in extracting solvent. Methanol extracts were relatively more effective than aqueous extract. Out of three invasive plants studied Parthenium hysterophorus seemed more effective, for inhibiting the growth of bacterial strains with maximum zone of inhibition (24.85 $\mathrm{mm}$ diam.), shown against Enterococcus faecalis at a concentration of $200 \mathrm{mg} / \mathrm{ml}$. The demonstration of activity against all these organisms had shown that all three alien invasive species; Ageratum haustonianum, Mikania micrantha and Parthenium hysterophorus can be used to produce raw materials/substances for further development of diverse antibiotics with broad spectrum of activity.
\end{abstract}

Key words: Invasive alien plants, Antibacterial activity, Zone of Inhibition, Phytochemical screening.

\section{INTRODUCTION}

An invasive plants also referred to as indigenous or non-native, is one that has been introduced by humans intentionally or otherwise through human agency or accidently from one region to another. An alien species has been defined as a species that is non-native, nonindigenous, exotic, foreign and/or introduced to an ecosystem other than its natural home. Those alien species that colonize unmanageably out-compete the native species are known as invasive alien species. Invasive alien species are considered as the second biggest threat, after deforestation, to biodiversity conservation. They disrupt the ecology of natural ecosystem, displace the native plant and animal species as well as degrade the landscape's unique and diverse biological resources. Invasive alien species reduce biodiversity, replace 
economically important native plant species and decrease the investment in agriculture and silviculture, disrupt prevailing vegetation dynamics, alter nutrient cycling and cause changes in the pattern of plant succession. Several exotic plants have invaded the high-value biodiversity areas and have adversely affected the natural and semi-natural vegetation/ecosystems (Tripathi 2009). Farmers, taxonomists and ecologist are now well aware of the invasion of alien species into natural areas and associated negative effects on global patterns of native biodiversity. Once established some alien species have the ability to displace or replace native plant species the problem will likely worsen with time because of climatic changes that promote species migration worldwide.

The diverse bioclimatic zones of Nepal range from tropical to alpine favor the introduction of several alien species (Tiwari et al. 2005). These species have been spreading aggressively by colonizing several landscapes and ecosystems displacing the native ones (Lockwood et al. 2001). In search for characteristics of exotic plants that might serve as predictors of invasiveness, most studies have examined life-history traits rather than attributes that more directly reflect interactions with potential natural enemies and competitors in the plants' new ranges (Mack 1996). Recent advances have shown that such interactions are critical in determining invasiveness. Resistance of invasive plants to antimicrobial agents has become an increasingly important and pressing global problem. Exotics escaping pathogens to a greater extent are more invasive than those that are more heavily attacked by natural enemies in their new ranges, suggesting that invasive exotics may be better defended from enemies than non-invasive plants (Mitchell and Power 2003). Interactions with native competitors are also important. These species being aggressive compete for water, light, space and nutrients, hence are present in large quantities. By virtue of their better defenses and enhanced competitive ability, the invasive alien species may exhibit phytochemically unique exotics (Lockwood et al. 2001).

Invasive plants have important ecological and economic impacts world-wide and increasing attention is now being paid to eradication and management efforts (Pimental et al. 2000). Management of such alien invasive plant is necessary for conservation of biodiversity and native species. Antibacterial study of alien plants help to find the potentialities of effect of these plants on bacterial and fungal growth. Further phytochemical study also help to find the chemical constituents that may be useful for pharmaceutical formulation. So the result of this study may have great significance in the management of such invasive alien weed.

The present study focused on the qualitative screening of secondary metabolites from three invasive alien weeds and their antibacterial assay. The result of this type of study may provide potential health applications at affordable cost. This type of study also keenly represents one of the best avenues in searching for new economically important plants for medicine. Hence the study deals with the screening and scientific evaluation of bioactive compound possessing a diverse range of pharmacological properties that may in turn prove beneficial for the mankind along with the management of the weeds.

\section{MATERIALS AND METHODS}

\section{Collection of plant materials}

Three invasive alien plant species namely Ageratum haustonianum, Mikania micrantha, and Parthenium hysterophorus were collected for study in their vegetative stages. Parthenium hysterophorus was collected from roadside fallow 
land of Kirtipur $\left(27^{\circ} 40.20^{\prime} \mathrm{N} 85^{\circ} 17.32^{\prime}\right.$ E, alt. 1300 $\mathrm{m}$ asl) Ageratum haustonianum and Mikania micrantha were collected from the grassland of Kasara village, Chitwan National Park during the month of June to August, 2012. Leaves of all the selected plants were collected and shade dried. Dried samples were chopped, pulverized to powder and stored in zipper plastic for further analysis.

\section{Laboratory analysis}

Laboratory work was carried out in Laboratory of Central Department of Botany, Tribhuvan University, Kirtipur.

\section{Extraction of plant sample}

Plant samples from each species were individually extracted by soaking $25 \mathrm{~g}$ of finely ground plant material with $250 \mathrm{ml}$ of distilled water and methanol solvents separately in conical flasks, plugged with cotton and kept on a rotary shaker at 180-200 rpm for $24 \mathrm{~h}$. It was filtered through 3 layered muslin cloths and the supernatant was filtered through Whatman No. 1 filter paper. Each of the solvent extract was concentrated separately under reduced pressure. After complete solvent evaporation, each of the solvent extract was weighed and preserved at $5^{\circ} \mathrm{C}$ in air tight bottles until further use.

\section{Phytochemical study}

The samples were grinded in a blender and used for the phytochemical screening test. The extracts of all test plants were screened for the phytochemical constituents by using standard chemical test methods (Harborne 1998) with slight modifications.

Test for alkaloids: About $2.5 \mathrm{~g}$ of sample was extracted with methanol and evaporated to dryness and the residue was heated on a boiling water bath with $2 \mathrm{~N} \mathrm{HCl}(5 \mathrm{ml})$. The resulting mixture was centrifuged for $10 \mathrm{~min}$ at $3000 \mathrm{rpm}$ to remove filtrate. One $\mathrm{ml}$ of the filtrate was treated with a few drops of Mayer's reagent and the second one $\mathrm{ml}$ portion was treated with equal amount of Wagner's reagent. The samples were then observed for presence of turbidity or precipitation.

Test for flavonoids: About $2.5 \mathrm{~g}$ of sample was taken in each case heated with $10 \mathrm{ml}$ of ethyl acetate over steam bath for $3 \mathrm{~min}$. The mixture was filtered and $4 \mathrm{ml}$ of the filtrate was shaken with 1 $\mathrm{ml}$ of dilute ammonia solution. A yellow colouration was observed indicating a positive test for flavonoids.

Test for carotenes (Carr-Price test): The ether extract corresponding to $2 \mathrm{~g}$ of plant material was concentrated to give a residue. The residue was taken in chloroform and 2-3 drops of saturated solution of antimony trichloride $\left(\mathrm{SbCl}_{3}\right)$ added to it. Appearance of blue colour, which turned red later, showed the presence of carotene.

Test for tannins: About $0.5 \mathrm{~g}$ of sample was boiled in $20 \mathrm{ml}$ of water in a test tube and then filtered. A few drops of $0.1 \%$ ferric chloride solution was added and observed for brownish green or blue black colouration. A blue-black precipitate was taken as evidence for the presence of tannins.

Test for glycosides: About $0.2 \mathrm{~g}$ of powdered medicinal plant was taken in a test tube with $5 \mathrm{ml}$ of water and warmed it on a water bath for two min. Resulting solution of plant extract was filtered and pipetted off the supernatant liquid. Added 0.1 $\mathrm{ml}$ of Fehling A solution and then Fehling B solution until alkaline. Warmed the resulting solution on a water bath for two minutes and observed for ppt. The samples were observed for presence of precipitation.

Test for terpenoids (Salkowski test): Five $\mathrm{ml}$ of $\mathrm{MeOH}$ extract, corresponding to $2.5 \mathrm{~g}$ of plant material, was mixed in $2 \mathrm{ml}$ chloroform, and concentrated $\mathrm{H}_{2} \mathrm{SO}_{4}(3 \mathrm{ml})$ was carefully added to form a layer. A reddish brown colouration of the inter face was formed to show positive results for the presence of terpenoids. 
Test for saponins: About $2.5 \mathrm{~g}$ of the plant material was extracted with boiling water. After cooling, the extract was shaken vigorously to froth and was then allowed to stand for 15-20 min and classified for saponin content as follows: no froth = negative; froth less than $1 \mathrm{~cm}=$ weakly positive; froth $1.2 \mathrm{~cm}$ high = positive; and froth greater than $2 \mathrm{~cm}$ high $=$ strongly positive .

\section{Antibacterial assay}

For the antibacterial assay, different concentrations $(50,100,150,200 \mathrm{mg} / \mathrm{ml})$ of each extracts were prepared in respective solvents. The ability of various extracts to inhibit the growth of clinical bacteria were determined by disc diffusion method (Bauer et al. 1996, Parekh and Chand 2007) with some modifications considering the access and availability of equipments and chemicals.

Bacterial strain: Clinical bacterial strains namely Bacillus cereus, Enterococcus faecalis, Escherichia coli, Klebsiella pneumonia (ATCC), Proteus vulgaris, Shigella dysentriae and Staphylococcus aureus, were used for the screening of antibacterial properties. The bacterial strains used for the test were brought from Department of Microbiology, Teaching hospital. They were taken on slants and later cultured on Petri plates having nutrient broth.

Preparation of standard culture Inoculums: Nutrient broth was prepared with the help of manufactures (Hi- media) recommendation. It was sterilized by autoclaving at $15 \mathrm{lbs}$ pressure and $121^{\circ} \mathrm{C}$ for $2 \mathrm{~h}$ inside the conical flask. It was cooled and $10 \mathrm{ml}$ nutrient broth was poured in the sterilized petriplates. The bacterial strains to be tested were aseptically taken with the help of needle from primary cultured slants and were transferred to the sterilized petriplates containing nutrient broth and was inoculated overnight the incubator at $37^{\circ} \mathrm{C}$
Antibacterial test: Inhibition of bacterial growth was tested by using disc diffusion method (Bauer et al. 1996, Parekh and Chand 2007) with some modifications according to the lab facility and the time. $24 \mathrm{~h}$ old bacterial culture was taken in sterilized petriplates with the help of cotton swab and was suspended in $10 \mathrm{ml}$ distilled water. This was used for the bacterial test.

Preparation of test discs: The test disc (4 mm diameter) was made by punching the filter paper (292 grade). The discs were prepared by dipping and saturating sterilized filter paper in different concentrations of the plant extracts $(50 \mu \mathrm{g} / \mathrm{ml}, 100$ $\mu \mathrm{g} / \mathrm{ml}, 150 \mu \mathrm{g} / \mathrm{ml}, 200 \mu \mathrm{g} / \mathrm{ml}$ and control). Solvent used in extraction; distilled water and methanol were used as control. The discs were air dried in the laminar flow.

Preparation of Nutrient Agar: 7 g nutrient agar and $2 \mathrm{~g}$ bacterial agar was dissolved in $250 \mathrm{ml}$ of distilled water (HI media method recommended) by continuous stirring until the media started to boil. This was transferred into the conical flask and was sterilized by autoclaving at $15 \mathrm{lbs}$ pressure and $121^{\circ} \mathrm{C}$ for $2 \mathrm{~h}$. Then the media was transferred to laminar flow and let it cool down for some time then it was poured almost $10-10 \mathrm{ml}$ in each sterilized petriplates and was left to solidify for 15 $20 \mathrm{~min}$

Inoculation of bacteria on petriplates: The Nutrient agar plates for the assay were prepared by drawing in each petriplates 6 chamber and labeling them with the date, code name of the bacteria and the dices code. The inoculums of bacteria were transferred into petriplates containing solidified media using sterile cotton swab. The sterile cotton swab was dipped into well mixed distilled water test culture and was spread on the media by moving the swab in Z-shape. One swab was used for one bacterium. Seven replicates were used for each bacterium. The culture plates were allowed to 
dry for 5-10 min. Then in each petriplate's in each chamber different concentrated dices were put with the help of sterile forceps. The plates were then incubated at $37 \pm 1^{\circ} \mathrm{C}$ for $24 \mathrm{~h}$. Microbial growth was determined by measuring the diameter of zone of inhibition (ZOI), indicated by the clear zone around the disc after incubation.

\section{RESULTS}

\section{Phytochemical screening}

Phytochemical screening of the plants under study is given in Table 1. Alkaloids, flavonoids tannins, terpenoids, glycosides and saponins were the phytochemicals present in the plants. Alkaloids were present in all studied plant samples in varied amount. Carotene was absent in all samples. Responses to various tests were denoted by,+++ and +++ signs indicating weak, moderate and strong reactions respectively while - for no reaction.

\section{Antibacterial activity}

The effects of plant extracts from three invasive alien plants species on growth of bacterial strains varied with plant species, and concentration of extract and type of solvent used. Effect was increased with increasing concentration of extract (Tables 2-9). Growth inhibition was significantly higher at $200 \mathrm{mg} / \mathrm{ml}$ concentration of extract. Result showed that methanolic extract of plant species had more inhibitory effect than aqueous extract.

Growth of Bacillus cereus was effected by aqueous and methanolic extract of different alien plant species. There was significant difference among the concentration and plant species (Table 2). Effect of growth increased with increasing concentration. Highest inhibitory effect was shown at $200 \mathrm{mg} / \mathrm{ml}$ concentration. Among the plant species tested Mikania micrantha had highest inhibitory effect on Bacillus cereus. Maximum zone of inhibition (14.14 mm) was shown by Mikania micrantha methanolic extract at 200 $\mathrm{mg} / \mathrm{ml}$ concentration and least i.e growth was not effected at lower concentration of Parthenium hysterophorus.

Growth of Staphylococcus aureus was also inhibited by different plant extract. Effect on growth was concentration dependent and species of plant. Growth of bacterium was not effected at lower concentration of aqueous extract of plant species; Ageratum haustonianum, Mikania micrantha and Parthenium hysterophorus but at higher concentration it was effected by all plant extract. Maximum zone of inhibition $(23.85 \mathrm{~mm})$ was exhibited by Parthenium hysterophorus at 200 $\mathrm{mg} / \mathrm{ml}$ and minimum (5.75 mm) ZOI was shown by Parthenium hysterophorus at same concentration (Table 3). Least zone of inhibiton $(7.85 \mathrm{~mm})$ against Staphylococcus aureus was exhibited by Ageratum haustonianum.

Growth of Enterococcus faecalis bacterium was effected significantly by both aqueous and methanolic extracts of selected invasive alien plants (Table 4). Effect was increased with increasing concentration in both solvents. Among the tested plants, aqueous extract of Mikania micrantha at $200 \mathrm{mg} / \mathrm{ml}$ concentration had highest ZOI (13.28 mm), while it was maximum (24.85 $\mathrm{mm}$ ) in methanolic extract of Parthenium hysterophorus at same concentration.

The effect of plant extracts from three invasive alien plants on growth of Schigella dysentriae varied with plant species and concentration of extract (Table 5). Maximum zone of inhibition was exhibited by Ageratum haustonianum in both aqueous $(9.0 \mathrm{~mm})$ and methanol extracts (13.45 $\mathrm{mm})$. Of the 3 plant species tested, both aqueous and methanolic extracts from leaves of Parthenium hysterophorus and Mikania micrantha did not show effect on growth of Schigella dysentriae. 
Table 1. Phytochemical constituents in leaves of three invasive alien plants studied.

\begin{tabular}{|c|c|c|c|c|c|c|c|}
\hline \multirow[t]{2}{*}{ Plants species } & \multicolumn{7}{|c|}{ Phytochemical constituents } \\
\hline & Alkaloids & Flavonoids & Carotene & Tannins & Terpenoid & Glycosides & Saponins \\
\hline Ageratum haustonianum & ++ & + & - & - & +++ & - & + \\
\hline Mikania micrantha & + & + & - & ++ & + & ++ & + \\
\hline Parthenium hysterophorus & + & + & - & + & + & + & + \\
\hline
\end{tabular}

If PPT is slight $=+$, Medium $=++$, Heavy $=+++$, Not $=-$

Table 2. Effect of three alien invasive species on growth of bacterial strain - Bacillus cereus. Significant difference between mean zone of inhibition (ZOI) among three invasive alien plants are indicated by different letters (Duncan homogeneity test, $\alpha=0.05$ ). $F$ and $P$ values were obtained by one way analysis of variance (ANOVA). (n=7).

\begin{tabular}{|c|c|c|c|c|c|c|c|c|}
\hline \multirow[t]{3}{*}{ Plant species } & \multicolumn{4}{|c|}{ Aqueous Extract (mg/ml) } & \multicolumn{4}{|c|}{ Methanolic extract $(\mathrm{mg} / \mathrm{ml})$} \\
\hline & 50 & 100 & 150 & 200 & 50 & 100 & 150 & 200 \\
\hline & \multicolumn{8}{|c|}{ Zone of inhibition displayed by different types and concentration of extracts (ZOI:mm) } \\
\hline Ageratum haustonianum & $5.50 \pm 1.12^{\mathrm{b}}$ & $6.20 \pm 2.02^{\mathrm{b}}$ & $7.50 \pm 0.92^{\mathrm{c}}$ & $9.5 \pm 2.02^{\mathrm{a}}$ & $7.5 \pm 1.84^{\mathrm{c}}$ & $7.17 \pm 2.12^{\mathrm{d}}$ & $7.64 \pm 3.02^{\mathrm{a}}$ & $7.0 \pm 2.12^{\mathrm{a}}$ \\
\hline Mikania micrantha & $6.0 \pm 1.82^{\mathrm{b}}$ & $5.85 \pm 2.12^{\mathrm{a}}$ & $6.0 \pm 1.12^{\mathrm{b}}$ & $7.5 \pm 2.17^{\mathrm{a}}$ & $9.07 \pm 1.02^{\mathrm{b}}$ & $11.57 \pm 1.0^{\mathrm{b}}$ & $13.35 \pm 1.0^{\mathrm{c}}$ & $14.14 \pm 1.01^{\mathrm{d}}$ \\
\hline Parthenium hysterophorus & $0.00^{\mathrm{a}}$ & $6.15 \pm 2.12^{\mathrm{a}}$ & $7.8 \pm 2.42^{\mathrm{c}}$ & $9.5 \pm 2.18^{\mathrm{a}}$ & $6.45 \pm 1.00^{\mathrm{a}}$ & $6.5 \pm 2.12^{\mathrm{a}}$ & $7.8 \pm 2.42^{\mathrm{a}}$ & $9.5 \pm 2.18^{\mathrm{b}}$ \\
\hline Control & $0.0^{\mathrm{a}}$ & $0.0^{\mathrm{a}}$ & $0.0^{\mathrm{a}}$ & $0.0^{\mathrm{a}}$ & $0.0^{\mathrm{a}}$ & $0.0^{\mathrm{a}}$ & $0.0^{\mathrm{a}}$ & $0.0^{\mathrm{a}}$ \\
\hline F- value & 31.74 & 243.22 & 183.5 & 5.97 & 1303 & 1651 & 767 & 2034 \\
\hline $\mathrm{p}$-value & 0.000 & 0.00 & 0.000 & 0.005 & 0.000 & 0.000 & 0.000 & 0.000 \\
\hline
\end{tabular}

Table 3. Effect of three alien invasive species on growth of bacterial strain - Staphylococcus aureus; Significant difference between mean zone of inhibition (ZOI) among three invasive alien plants are indicated by different letters (Duncan homogeneity test, $\alpha=$ $0.05)$. F and $P$ values were obtained by one way analysis of variance (ANOVA). (n=7).

\begin{tabular}{lcccccccc}
\hline Plant species & \multicolumn{4}{c}{ Aqueous extract (mg/ml) } & \multicolumn{3}{c}{ Methanolic extract (mg/ml) } \\
& $\mathbf{5 0}$ & $\mathbf{1 0 0}$ & $\mathbf{1 5 0}$ & $\mathbf{2 0 0}$ & $\mathbf{5 0}$ & $\mathbf{1 0 0}$ & $\mathbf{1 5 0}$ & $\mathbf{2 0 0}$ \\
& \multicolumn{3}{c}{ Zone of inhibition displayed by different types and concentration of extracts (ZOI:mm) $^{-}$} \\
\hline Ageratum haustonianum & 0.0 & $7.50 \pm 1.22^{\mathrm{d}}$ & $8.01 \pm 1.32^{\mathrm{d}}$ & $8.50 \pm 2.40^{\mathrm{b}}$ & $6.5 \pm 3.42^{\mathrm{c}}$ & $7.37 \pm 2.58^{\mathrm{b}}$ & $6.93 \pm 1.72^{\mathrm{d}}$ & $7.85 \pm 1.02^{\mathrm{d}}$ \\
Mikania micrantha & $0.0^{\mathrm{a}}$ & $5.0 \pm 2.42^{\mathrm{b}}$ & $4.5 \pm 1.42^{\mathrm{b}}$ & $6.5 \pm 2.13^{\mathrm{a}}$ & $11.42 \pm 1.12^{\mathrm{d}}$ & $12.64 \pm 1.21^{\mathrm{c}}$ & $13.71 \pm 1.23^{\mathrm{c}}$ & $15.85 \pm 1.10^{\mathrm{c}}$ \\
Parthenium hysterophorus & $0.0^{\mathrm{a}}$ & $0.0^{\mathrm{a}}$ & $5.60 \pm 2.13^{\mathrm{c}}$ & $5.75 \pm 2.14^{\mathrm{a}}$ & $21.71 \pm 2.2^{\mathrm{e}}$ & $21.21 \pm 2.18^{\mathrm{d}}$ & $21.35 \pm 2.12^{\mathrm{d}}$ & $23.85 \pm 3.12^{\mathrm{d}}$ \\
Control & $0.0^{\mathrm{a}}$ & $0.0^{\mathrm{a}}$ & $0.0^{\mathrm{a}}$ & $0.0^{\mathrm{a}}$ & $0.0^{\mathrm{a}}$ & $0.0^{\mathrm{a}}$ & $0.0^{\mathrm{a}}$ & $0.0^{\mathrm{a}}$ \\
F Value & 150.60 & 32.66 & 11.76 & 9.63 & 681.64 & 1877 & 1226 & 844 \\
P value & 0.000 & 0.000 & 0.000 & 0.001 & 0.000 & 0.000 & 0.000 & 0.000 \\
\hline
\end{tabular}

There was significant effect of plant extract on growth of Klebsiella pneumonia. At lower concentration $(50 \mathrm{mg} / \mathrm{ml})$, aqueous extract of Mikania micrantha and Parthenium hysterophorus did not show any effect on growth of bacterium (Table 6); but effect was shown at higher concentration. Maximum zone of inhibition was exhibited by aqueous extract of Ageratina adenophora at $200 \mathrm{mg} / \mathrm{ml}$ concentration.
All plant extracts had significantly inhibited the growth of Salmonella paratyphi in vitro compared to control treated with sterile distilled water for aqueous extract and methanol in case for methanol extract. The antibacterial activity of aqueous extract of three alien invasive plant extract was ranged from inhibition diameter of $0.00 \mathrm{~mm}$ at lower concentration to $11.2 \mathrm{~mm}$ at higher concentration (Table 7). The highest diameter of 
inhibition zone (11.2) was recorded from Parthenium hysterophorus at $200 \mathrm{mg} / \mathrm{ml}$ concentration that was statistically different from other plant extract and concentration. The in vitro inhibitory activity of methanol extract against the Salmonella paratyphi ranged from inhibition diameter of $6.0 \mathrm{~mm}$ at lower concentration to 14.0 $\mathrm{mm}$ at higher concentration. Highest diameter of inhibition zone $(14.0 \mathrm{~mm})$ was recorded from Ipomoea carnea at $200 \mathrm{mg} / \mathrm{ml}$ concentration; and lowest $(8.56 \mathrm{~mm})$ was exhibited by Mikania micrantha at same concentration.
The antibacterial activity of aqueous extract of three alien invasive plant on Proteus vulgaris was ranged from inhibition diameter of $0.00 \mathrm{~mm}$ at lower concentration to $6.2 \mathrm{~mm}$ at higher concentration (Table 8). The highest diameter of inhibition zone $(6.2 \mathrm{~mm})$ was recorded from Parthenium hysterophorus aqueous extract of at $200 \mathrm{mg} / \mathrm{ml}$ concentration. The highest diameter of inhibition zone $(14.42 \mathrm{~mm})$ was recorded from methanolic extract of Mikania micrantha at 200 $\mathrm{mg} / \mathrm{ml}$ concentration that was statistically different from other plant extract and concentration.

Table 4. Effect of three alien invasive species on growth of bacterial strain- Enterococcus faecalis; Significant difference between mean zone of inhibition (ZOI) among three invasive alien plants are indicated by different letters (Duncan homogeneity test, $\alpha=0.05$ ). $F$ and $P$ values were obtained by one way analysis of variance (ANOVA). (n=7).

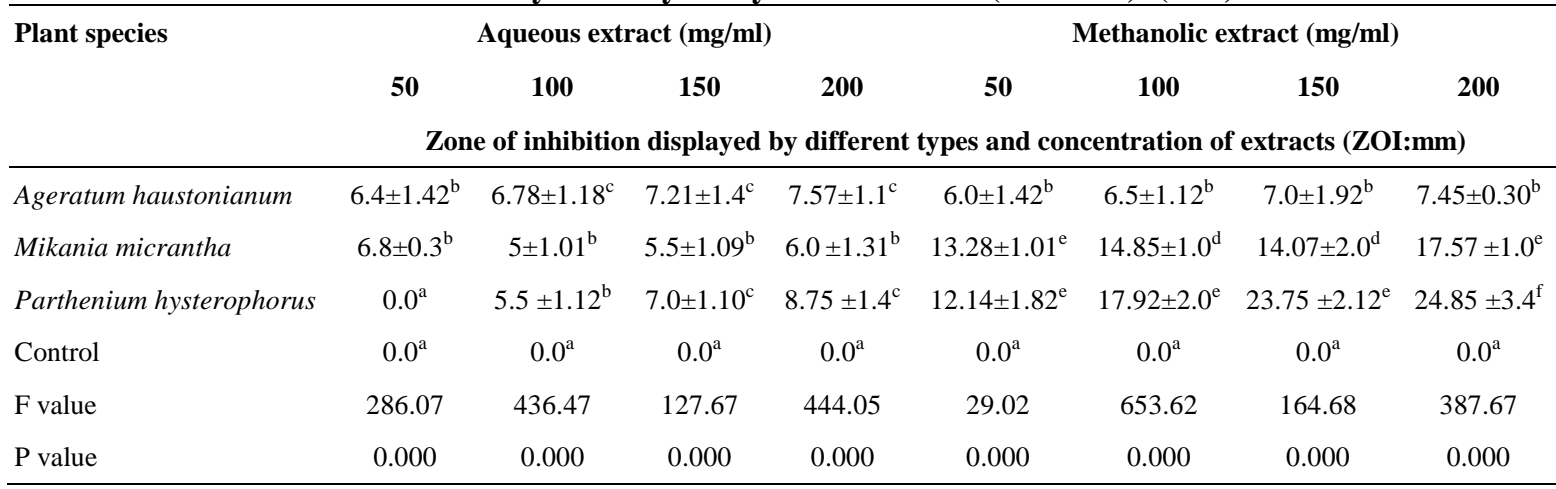

Table 5. Effect of three alien invasive species on growth of bacterial strain- Schigella dysentriae; Significant difference between mean zone of inhibition (ZOI) among three invasive alien plants are indicated by different letters (Duncan homogeneity test, $\alpha=0.05$ ). $F$ and $P$ values were obtained by one way analysis of variance (ANOVA). (n=7).

\begin{tabular}{|c|c|c|c|c|c|c|c|c|}
\hline \multirow[t]{3}{*}{ Plant species } & \multicolumn{4}{|c|}{ Aqueous extract (mg/ml) } & \multicolumn{4}{|c|}{ Methanolic extract(mg/ml) } \\
\hline & 50 & 100 & 150 & 200 & 50 & 100 & 150 & 200 \\
\hline & \multicolumn{8}{|c|}{ Zone of inhibition displayed by different types and concentration of extracts (ZOI:mm) } \\
\hline Ageratum haustonianum & $7.8 \pm 1.60^{\mathrm{b}}$ & $8.20 \pm 2.19^{c}$ & $8.0 \pm 2.18$ & $9.0 \pm 2.10^{b}$ & $11.45 \pm 1.94^{\mathrm{b}}$ & $12.0 \pm 2.02$ & $12.55 \pm 2.10^{\mathrm{c}}$ & $13.45 \pm 1.12^{\mathrm{c}}$ \\
\hline Mikania micrantha & $0.0^{\mathrm{a}}$ & $0.00^{\mathrm{a}}$ & $0.00^{\mathrm{a}}$ & $0.00^{\mathrm{a}}$ & $0.00^{\mathrm{a}}$ & $0.00^{\mathrm{a}}$ & $0.00^{\mathrm{a}}$ & $0.00^{\mathrm{a}}$ \\
\hline $\begin{array}{l}\text { Parthenium } \\
\text { hysterophorus }\end{array}$ & $0.0^{\mathrm{a}}$ & $0.00^{\mathrm{a}}$ & $0.00^{\mathrm{a}}$ & $0.00^{\mathrm{a}}$ & $0.00^{\mathrm{a}}$ & $0.00^{\mathrm{a}}$ & $0.00^{\mathrm{a}}$ & $0.00^{\mathrm{a}}$ \\
\hline Control & $0.0^{\mathrm{a}}$ & $0.00^{\mathrm{a}}$ & $0.00^{\mathrm{a}}$ & $0.00^{\mathrm{a}}$ & $0.00^{\mathrm{a}}$ & $0.00^{\mathrm{a}}$ & $0.00^{\mathrm{a}}$ & $0.00^{\mathrm{a}}$ \\
\hline F value & 8.68 & 170.95 & 170.95 & 16.49 & 434.5 & 451 & 302 & 214 \\
\hline $\mathrm{p}$ - value & 0.001 & 0.000 & 0.000 & 0.000 & 0.000 & 0.000 & 0.000 & 0.000 \\
\hline
\end{tabular}


Table 6. Effect of three alien invasive species on growth of bacterial strain- Klebsiella pneumonia Significant difference between mean zone of inhibition (ZOI) among three invasive alien plants are indicated by different letters (Duncan homogeneity test, $\alpha=0.05$ ). F and $P$ values were obtained by one way analysis of variance (ANOVA). (n=7).

\begin{tabular}{|c|c|c|c|c|c|c|c|c|}
\hline \multirow[t]{3}{*}{ Plant species } & \multicolumn{4}{|c|}{ Aqueous extract (mg/ml) } & \multicolumn{4}{|c|}{ Methanolic extract $(\mathrm{mg} / \mathrm{ml})$} \\
\hline & $\mathbf{5 0}$ & 100 & 150 & 200 & 50 & 100 & 150 & 200 \\
\hline & \multicolumn{8}{|c|}{ Zone of inhibition displayed by different types and concentration of extracts (ZOI:mm) } \\
\hline Ageratum haustonianum & $6.71 \pm 0.4^{\mathrm{b}}$ & $7.07 \pm 1.12^{\mathrm{c}}$ & $7.21 \pm 2.41^{\mathrm{c}}$ & $7.85 \pm 2.0^{\mathrm{c}}$ & $0.00^{\mathrm{a}}$ & $0.00^{\mathrm{a}}$ & $0.00^{\mathrm{a}}$ & $0.00^{\mathrm{a}}$ \\
\hline Mikania micrantha & $0.00^{\mathrm{a}}$ & $6.01 \pm 2.02^{\mathrm{b}}$ & $5.5 \pm 1.52^{\mathrm{b}}$ & $6.0 \pm 1.12^{\mathrm{b}}$ & $14 \pm 0.89$ & $16.78 \pm 0.9^{d}$ & $15.42 \pm 1.21^{\mathrm{c}}$ & $16.07 \pm 1.0^{\mathrm{c}}$ \\
\hline Parthenium hysterophorus & $0.00^{\mathrm{a}}$ & $5.5 \pm 2.90^{\mathrm{b}}$ & $7.5 \pm 2.08^{\mathrm{c}}$ & $7.5 \pm 1.12^{\mathrm{c}}$ & $16.5 \pm 2.3^{\mathrm{c}}$ & $17.78 \pm 2.1^{\mathrm{d}}$ & $20.14 \pm 2.18^{\mathrm{d}}$ & $21.85 \pm 2.1^{\mathrm{d}}$ \\
\hline Control & $0.0^{\mathrm{a}}$ & $0.00^{\mathrm{a}}$ & $0.00^{\mathrm{a}}$ & $0.00^{\mathrm{a}}$ & $0.00^{\mathrm{a}}$ & $0.00^{\mathrm{a}}$ & $0.00^{\mathrm{a}}$ & $0.00^{\mathrm{a}}$ \\
\hline $\mathrm{F}$ value & 58.90 & 132 & 109 & 131 & 121 & 805 & 1271 & 882 \\
\hline$P$ value & 0.000 & 0.000 & 0.000 & 0.000 & 0.000 & 0.000 & 0.000 & 0.000 \\
\hline
\end{tabular}

Table 7. Effect of three alien invasive species on growth of bacterial strain - Salmonella paratyphi; Significant difference between mean zone of inhibition (ZOI) among three invasive alien plants are indicated by different letters (Duncan homogeneity test, $\alpha=0.05$ ). F and $P$ values were obtained by one way analysis of variance (ANOVA). $(n=7)$.

\begin{tabular}{|c|c|c|c|c|c|c|c|c|}
\hline \multirow[t]{3}{*}{ Plant sp } & \multicolumn{4}{|c|}{ Aqueous extract (mg/ml) } & \multicolumn{4}{|c|}{ Methanolic extract (mg/ml) } \\
\hline & 50 & 100 & 150 & 200 & 50 & 100 & 150 & 200 \\
\hline & \multicolumn{8}{|c|}{ Zone of inhibition displayed by different types and concentration of extracts (ZOI:mm) } \\
\hline Ageratum haustonianum & $2.34 \pm 2.10^{b}$ & $8.50 \pm 2.1^{\mathrm{d}}$ & $9.6 \pm 1.12^{\mathrm{e}}$ & $10.0 \pm 1.22^{\mathrm{d}}$ & $8.0 \pm 2.02^{\mathrm{e}}$ & $10.50 \pm 2.17^{\mathrm{d}}$ & $11.85 \pm 2.81^{\mathrm{e}}$ & $16 \pm 1.42^{\mathrm{f}}$ \\
\hline Mikania micrantha & $0.00^{\mathrm{a}}$ & $0.00^{\mathrm{a}}$ & $0.00^{\mathrm{a}}$ & $6.46 \pm 2.21^{\mathrm{b}}$ & $6.00 \pm 1.05^{\mathrm{b}}$ & $6.71 \pm 0.21^{\mathrm{b}}$ & $6.96 \pm 1.23^{\mathrm{b}}$ & $8.56 \pm 1.21^{\mathrm{b}}$ \\
\hline Parthenium Hysterophorus & $0.00^{\mathrm{a}}$ & $4.8 \pm 2.12^{c}$ & $6.5 \pm 2.01^{\mathrm{c}}$ & $11.2 \pm 1.02^{\mathrm{e}}$ & $7.5 \pm 2.10^{\mathrm{de}}$ & $8.5 \pm 2.09^{c}$ & $10.4 \pm 2.05^{\mathrm{d}}$ & $13.5 \pm 2.02^{\mathrm{d}}$ \\
\hline Control & $0.0^{\mathrm{a}}$ & $0.00^{\mathrm{a}}$ & $0.00^{\mathrm{a}}$ & $0.00^{\mathrm{a}}$ & $0.00^{\mathrm{a}}$ & $0.00^{\mathrm{a}}$ & $0.00^{\mathrm{a}}$ & $0.00^{\mathrm{a}}$ \\
\hline F value & 128 & 568 & 982 & 486 & 37.54 & 50.54 & 289 & 121 \\
\hline $\mathrm{P}$ value & 0.000 & 0.000 & 0.000 & 0.000 & 0.000 & 0.000 & 0.000 & 0.000 \\
\hline
\end{tabular}

Table 8. Effect of three alien invasive species on growth of bacterial strain - Proteus vulgaris. Significant difference between mean zone of inhibition (ZOI) among three invasive alien plants are indicated by different letters (Duncan homogeneity test, $\alpha=0.05$ ). F and $P$ values were obtained by one way analysis of variance (ANOVA). (n=7).

\begin{tabular}{|c|c|c|c|c|c|c|c|c|}
\hline \multirow[t]{3}{*}{ Plant sp } & \multicolumn{4}{|c|}{ Aqueous extract (mg/ml) } & \multicolumn{4}{|c|}{ Methanolic extract (mg/ml) } \\
\hline & 50 & 100 & 150 & 200 & 50 & 100 & 150 & 200 \\
\hline & \multicolumn{8}{|c|}{ Zone of inhibition displayed by different types and concentration of extracts (ZOI:mm) } \\
\hline Ageratum haustonianum & $0.00^{\mathrm{a}}$ & $0.00^{\mathrm{a}}$ & $0.00^{\mathrm{a}}$ & $0.00^{\mathrm{a}}$ & $9.85 \pm 1.02^{\mathrm{c}}$ & $11.67 \pm 0.98^{\mathrm{c}}$ & $11.85 \pm 1.0^{\mathrm{b}}$ & $12.71 \pm 1.20^{\mathrm{bc}}$ \\
\hline Mikania micrantha & $0.00^{\mathrm{a}}$ & $0.00^{\mathrm{a}}$ & $5.89 \pm 1.2^{\mathrm{c}}$ & $6.72 \pm 2.2^{\mathrm{b}}$ & $10.42 \pm^{\circ}$ & $11.57 \pm 0.98^{\mathrm{c}}$ & $13.64 \pm 1.09^{c}$ & $14.42 \pm 1.0^{\mathrm{d}}$ \\
\hline Parthenium hysterophorus & $0.00^{\mathrm{a}}$ & $5.83 \pm 2.3^{b}$ & $5.73 \pm 1.1^{\mathrm{c}}$ & $6.2 \pm 2.10^{\mathrm{b}}$ & $8.64 \pm 2.1^{b}$ & $11.28 \pm 2.12^{\mathrm{c}}$ & $11.0 \pm 2.11^{\mathrm{b}}$ & $13.71 \pm 2.10^{\mathrm{c}}$ \\
\hline Control & $0.0^{\mathrm{a}}$ & $0.00^{\mathrm{a}}$ & $0.00^{\mathrm{a}}$ & $0.00^{\mathrm{a}}$ & $0.00^{\mathrm{a}}$ & $0.00^{\mathrm{a}}$ & $0.00^{\mathrm{a}}$ & $0.00^{\mathrm{a}}$ \\
\hline F value & 112 & 98.0 & 404 & 128 & 421 & 211 & 123 & 241 \\
\hline$P$ value & 0.000 & 0.000 & 0.000 & 0.000 & 0.000 & 0.000 & 0.000 & 0.000 \\
\hline
\end{tabular}


Table 9. Effect of three alien invasive species on growth of bacterial strain - E. coli; Significant difference between mean zone of inhibition (ZOI) among three invasive alien plants are indicated by different letters (Duncan homogeneity test, $\alpha=0.05$ ). $F$ and $P$ values were obtained by one way analysis of variance (ANOVA). (n=7).

\begin{tabular}{lcccccccc}
\hline Plant species & \multicolumn{4}{c}{ Aqueous extract $(\mathbf{m g} / \mathbf{m l})$} & \multicolumn{4}{c}{ Methanolic extract (mg/ml) } \\
& $\mathbf{5 0}$ & $\mathbf{1 0 0}$ & $\mathbf{1 5 0}$ & $\mathbf{2 0 0}$ & $\mathbf{5 0}$ & $\mathbf{1 0 0}$ & $\mathbf{1 5 0}$ & $\mathbf{2 0 0}$ \\
& Mean zone of inhibition displayed by different types and concentration of extracts (ZOI:mm) \\
\hline Ageratum haustonianum & $6.0 \pm 1.21^{\mathrm{c}}$ & $6.28 \pm 0.98^{\mathrm{b}}$ & $6.78 \pm 1.1^{\mathrm{b}}$ & $7.85 \pm 1.1^{\mathrm{c}}$ & $6.0 \pm 0.98^{\mathrm{b}}$ & $6.28 \pm 1.12^{\mathrm{b}}$ & $.78 \pm 2.12^{\mathrm{b}}$ & $7.85 \pm 2.9^{\mathrm{b}}$ \\
Mikania micrantha & $0.00^{\mathrm{a}}$ & $0.00^{\mathrm{a}}$ & $0.00^{\mathrm{a}}$ & $0.00^{\mathrm{a}}$ & $12.57 \pm 1.0^{\mathrm{d}}$ & $15 \pm 1.56^{\mathrm{e}}$ & $16.78 \pm 1.3^{\mathrm{e}}$ & $16.87 \pm 0.9^{\mathrm{e}}$ \\
Parthenium hysterophorus & $0.00^{\mathrm{a}}$ & $0.00^{\mathrm{a}}$ & $0.00^{\mathrm{a}}$ & $0.00^{\mathrm{a}}$ & $9.07 \pm 1.12^{\mathrm{c}}$ & $10.28 \pm 2.1^{\mathrm{c}}$ & $10.0 \pm 2.31^{\mathrm{c}}$ & $10.78 \pm 2.02^{\mathrm{c}}$ \\
Control & $0.0^{\mathrm{a}}$ & $0.00^{\mathrm{a}}$ & $0.00^{\mathrm{a}}$ & $0.00^{\mathrm{a}}$ & $0.00^{\mathrm{a}}$ & $0.00^{\mathrm{a}}$ & $0.00^{\mathrm{a}}$ & $0.00^{\mathrm{a}}$ \\
F value & 314 & 209 & 542 & 601 & 1548 & 248 & 551 & 478 \\
P value & 0.000 & 0.000 & 0.000 & 0.000 & 0.000 & 0.000 & 0.000 & 0.000 \\
\hline
\end{tabular}

The antibacterial activity of aqueous extract of three alien invasive plant on $E$. coli was ranged from inhibition diameter of $0.00 \mathrm{~mm}$ at lower concentration to $9.5 \mathrm{~mm}$ at higher concentration (Table 9). The highest diameter of inhibition zone $(7.85 \mathrm{~mm})$ was recorded from aqueous extract of Ageratum haustanianum at $200 \mathrm{mg} / \mathrm{ml}$ concentration. Out of three plant species tested, aqueous extract of four plant species Mikania micrantha, and Parthenium hysterophorus did not show effect on growth of E. coli. The highest diameter of inhibition zone $(16.87 \mathrm{~mm})$ was recorded from methanolic extract of Mikania micrantha at $200 \mathrm{mg} / \mathrm{ml}$ concentration that was statistically different from other plant extract and concentration.

\section{DISCUSSION}

Phytochemical analysis of the plant extract showed that it contains alkaloids, flavonoids, tannins, terpenoids glycosides and saponins (Table 1). The methanol, and aqueous extracts of the leaves of Ageratum haustonianum, Mikania micrantha and Parthenium hysterophorus were subjected to a preliminary screening for antimicrobial activity against seven human pathogenic bacteria.
It was clear from the present results, that both aqueous and methanol leaves extracts of Ageratum haustonianum, Mikania micrantha and Parthenium hysterophorus exhibited pronounced activity against almost all tested microbes in a concentration depended manner (Tables 2-9). However antimicrobial effect varied with species of plants and species of micro-organisms. For example methanolic extracts from leaves of Parthenium hysterophorus were highly effective in inhibition of growth of Enterococcus faecalis; Ageratum haustonianum methanolic extracts were effective in inhibition of growth of Schigella dysentriae; and methanolic extracts of Mikania micrantha were effective in inhibition of growth of E.coli. In other species there was moderate to negligible effect on growth of bacterial strains. Thus out of three invasive alien plant species studied Parthenium hysterophorus seemed more effective for inhibiting the growth of three bacterial strains with maximum zone of inhibition (Enterococcus faecalis $24.85 \mathrm{~mm}$ at a concentration of $200 \mathrm{mg} / \mathrm{ml}$ ). The observed antibacterial effects may be due to the presence of phytochemicals (alkaloids, tannins and saponins) in the extract. The optimal effectiveness of a plant may not be due to one main active constituent, but to the combined action of different compounds originally present in the plant (Gonzalez et al. 1994). 
In the present study Enterococcus faecalis was the most susceptible bacterium (ZOI; $24.85 \mathrm{~mm}$ at methanolic extract of Parthenium hysterophorus, at concentration of $200 \mathrm{mg} / \mathrm{ml}$ ) and Schigella dysentriae and E.coli were the most resistant bacteria among the tested organisms as growth of these bacteria were not effected by majority of plant extract (Tables 5 and 9). It has been suggested that the antibacterial activity of plant secondary metabolites is mainly due to presence of essential oil, flavonoids and tri- terpenoids and other natural polyphenolic compounds or free hydroxyl groups (Rojas et al. 1992). The observed antibacterial effects in present study also may be due to the presence of phytochemicals (alkaloids, tannins and saponins) in the extract.

The results of this study support the antibacterial activities of three invasive alien plants as a broad spectrum antimicrobial agent since they inhibited the growth of Gram-positive (B cereus, $S$. aureus, E. faecalis) and gram negative bacteria ( $E$. coli, $P$. vulgaris, $K$. pneumonia and $S$. dysentriae). The present study is in accordance with the works of Okunola et al. (2012), who reported higher antimicrobial activities of extracts of Carica papaya in bacterial strains.

Results of present study is also supported by Barsagade and Wagh (2010), who indicated antibacterial activities of plants and weed extracts may exist in a variety of different components, including aldehyde and phenolic compounds. Variation in effectiveness of the extract against a target microorganisms depends upon the chemical compositions of the extract and membrane permeability of the microbe for the chemicals. Naturally occurring combination of these compounds can be synergistic and often results in crude extracts having greater antibacterial activity than the purified individual constituents. The antibacterial effects of the extracts could be explained by disturbance of the permeability barrier of the living membrane structure (Cowan 1999).

Results from in vitro study revealed that the antibacterial activity might have been influenced by the solubility of active compound (s) in extracting solvent. Methanol extracts were relatively more effective than aqueous extract. This greater effectiveness of methanol extract compared to aqueous extract may be due to differences in constituents and amount of extraction of phytochemicals, which are toxic to targeted pathogens, present in leaf parts of tested invasive alien plants.

The leaf extracts of selected plants contain alkaloids, coumarins and tannins (Table 1). Coumarins and tannins have antibacterial and antihelminthic properties (Hedberg et al. 1983), also Eloff (1998) and Cowan (1999) found that methanol was more efficient than distilled water in extracting phytochemicals from plant materials. The absence or less effect of antimicrobial activity of aqueous extracts of plant extract indicates the insolubility of the active ingredients in this solvents. Similar observations were reported from nimbolide isolated from neem seed oil showing antibacterial activity against $S$. aureus and Staphylococcus coagulase (Nazma and Rao 1977). Also antibacterial effects of neem extract have been demonstrated against Streptococcus mutans and S. faecalis (Almas 1999). These might be due to presence of triterpenoids, phenolic compounds, carotenoids, steroids, flavinoids, ketones and tetratriterpenoids azadirachtin (Kraus 1995).

Plant products, particularly extracts of various plant parts have been used extensively as natural antimicrobials and antioxidants. The presence of bioactive substances has been reported to confer resistance to plants against bacteria, fungi and pests and therefore explains the demonstration of antibacterial activity by the plants extract used in this study (Srinivasan et al. 2001). Results of this

ECOPRINT VOL 23, 2016 
study revealed very significant antibacterial activity with the extracts demonstrating broad spectrum of activity against bacteria (B. cereus, $S$. aureus, K. pneumonia, E. faecalis, P. vulgaris, $S$. dysentriae and E. coli). The organisms used in this study are associated with various forms of infections in human. The bacteria are associated with gastrointestinal infections, dysentery and urinary tract infections (E. coli, E. faecalis), pneumonia, bronchitis (K. pneumonia), Kidney stones ( $P$. vulgaris), Bacillary dysentery $(S$. dysentriae) and urinary tract infections ( $S$. aureus). The demonstration of activity against all these organisms had shown that all three alien invasive species; Ageratum haustonianum, Mikania micranths, and Parthenium hysterophorus can be used to produce raw materials/substances for further development of diverse antibiotics with broad spectrum of activity.

Continued further exploration of plant-derived antimicrobials is needed today. Further research is necessary to determine the identity of the antimicrobial compounds from within these plants and also to determine their full spectrum of efficacy.

\section{CONCLUSION}

Out of three invasive alien plant species studied Parthenium hysterophorus seemed more effective for inhibiting the growth of bacterial strains with maximum zone of inhibition (24.85 mm diam.) shown against Enterococcus faecalis at a concentration of $200 \mathrm{mg} / \mathrm{ml}$ ). All these organisms had shown that all three alien invasive species; Ageratum haustonianum, Mikania micrantha and Parthenium hysterophorus can be used to produce raw materials/substances for further development of diverse antibiotics with broad spectrum of activity.

\section{ACKNOWLEDGEMENT}

Financial support for this research from University Grants Commission, Nepal is thankfully acknowledged.

\section{REFERENCES}

Almas, K. 1999. The antimicrobial effects of extracts of Azadirachta indica (Neem) and Salvadora persica (Arak) chewing sticks. Indian. J. Dent. Res. 10:23-26.

Barsagade, N.B. and G.N. Wagh. 2010. Comparative screening of leaf extracts of common plants and weeds for their antibacterial and antifungal activities. Asiatic Journal of Biotechnology Resources 3:227232.

Bauer, A.W., W.M. Kirby, J.C. Sherris and M. Turck. 1996. Antibiotic susceptibility testing by standardized single disc method. Am. J. Clin. Pathol. 44:493-496.

Cowan, M.M. 1999. Plant products as antimicrobial agents. Clinical Microbiology Reviews 12:564-582.

Eloff, J.N. 1998. Which extractant should be used for the screening and isolation of antimicrobial components from plants? Journal of Ethnopharmacology 60:1-8.

Gonzalez, A., G. Moukir, I. Bazzocchi, I.L. Correa and M.D. Gupta. 1994. Screening of antimicrobial and cytotoxic activities of Panamanian plants. Phytomedicine 1:149-153.

Harborne, J.B. 1998. Phytochemical Methods-A Guide to Modern Techniques of Plant Analysis. Chapman and Hall, London.

Hedberg, I., O. Hedberg, P. Madati, K.E. Mshigeni, E.N. Mshiu, and G. Samuelsson. 1983. Inventory of plants used in traditional medicine in Tanzania. II. Plants of the family Dilleniaceae to Opiliaceae. Journal of Ethnopharmacology 9:105-128. 
Lockwood, J.L., D. Simberloff, M.L. McKinney, and B. Holle. 2001. How many, and which, plants will invade natural areas. Bio Invasions 3:1-8.

Mack, R.M. 1996. Predicting the identity and fate of plant invaders: Emergent and emerging approaches. Biol. Conservation 78:107-121.

Mitchell, C.E. and A.G. Power. 2003. Release of invasive plants from fungal and viral pathogens. Nature 421:625-627.

Nazma, B.S.V. and J.M. Rao. 1977. Antifungal activity of Gedunin. Curr. Sci. 46:714-715.

Okunola, P., M. Ibadin, G. Ofovwe and G. Ukoh. 2012. Coexistence of UTI and malaria among children under five years old. A report from Benin City, Nigeria. Saudi J. Kidney Dis. Transpl. 23(3):629-634.

Parekh, J. and S.V. Chand. 2007. In vitro antimicrobial activity and phytochemical analysis of some Indian medicinal plants. Turkish Journal of Biology 31:53-58.

Pimental, D., R. Zuniga and D. Morrison. 2000. Environmental and economic costs of nonindigenous species in the United States. Bioscience 50:53-65.

Rojas, A., L. Hernandez, R. Pereda-Miranda and R. Mata. 1992. Screening for antimicrobial activity of crude drug extracts and pure natural products from Mexican medicinal plants. Journal of Ethnopharmacology 35:275-285.

Srinivasan, D., L.P. Perumalsamy and T. Sures. 2001. J. Ethnopharmacology 94:217-222.

Tiwari, S., B. Adhikari, M. Siwakoti and K. Subedi. 2005. An Inventory and Assessment of Invasive Alien Plant Species of Nepal. IUCN Nepal, Kathmandu.

Tripathi, R.S. 2009. Alien Plant Invasion: A Hot Ecological Issue. International Society of Environmental Botanist 15(3). 